\title{
Phosphorus analysis in soil under herbaceous perennial leguminous cover by nuclear magnetic spectroscopy
}

Luciano Pasqualoto Canellas(1), José Antônio Azevedo Espíndola(2), José Guilherme Marinho Guerra(2), Marcelo Grandi Teixeira ${ }^{(2)}$, Ary Carlos Xavier Velloso ${ }^{(1)}$ and Victor Marcos Rumjanek ${ }^{(3)}$

(1)Universidade Estadual do Norte Fluminense, Laboratório de Solos, Av. Alberto Lamego, 2000, Parque Califórnia, CEP 28013-602 Campos dos Goytacazes, RJ, Brazil. E-mail canellas@uenf.br (2)Embrapa Agrobiologia, km 7, BR 467, CEP 23851-970 Seropédica, Brazil. E-mail: Jose@cnpab.embrapa.br, gmguerra@cnpab.embrapa.br, grandi@cnpab.embrapa.br (3)Universidade Federal Rural do Rio de Janeiro, Dep. de Química, CEP 23851-970 Seropédica, RJ, Brazil. E-mail: rumjanek@ufrrj.br

Abstract - The availability and the reserves of organic phosphorus are controlled by its mineralization rate and are also influenced by changes in soil management. The objective of this study was to evaluate the influence of soil covering with different leguminous plant on soil organic $\mathrm{P}$ by ${ }^{31} \mathrm{P}-\mathrm{NMR}$ spectroscopy. Alkaline soil extracts were obtained from two depths $(0-5$ and $5-10 \mathrm{~cm})$ of an Ultisol cultivated with herbaceous perennial leguminous plants (Arachis pintoi, Pueraria phaseoloides, Macroptilium atropurpureum). In an adjacent area, samples of the same soil cover with a secondary tropical forest and grass (Panicum maximum) were also collected. The leguminous management was divided into with removal and without removal of shoot parts after cut on soil surface. Phosphate monoesters are the dominant $\mathrm{P}$ species in all soil samples and $\mathrm{P}$ diesters accumulated on the superficial layer of secondary forest soil. The $\mathrm{P}$ amount of this fraction is higher for the legume covered soil when compared with the grass covered soil. The permanence of leguminous plants on the topsoil after the cut promoted an increase in $\mathrm{P}$ diester/P monoester ratios. These findings can be accounted for an enhancement of $\mathrm{P}$ availability to plants in soils cultivated with leguminous plants.

Index terms: cultivation, deforestation, cover crops.

\section{Análise de fósforo em solo com leguminosas herbáceas perenes por meio de ressonância magnética nuclear}

Resumo - A disponibilidade e as reservas de fósforo orgânico são controladas pela taxa de mineralização e influenciadas pelas alterações no manejo do solo. O objetivo deste trabalho foi avaliar o fósforo orgânico mediante espectroscopia de ressonância magnética nuclear de ${ }^{31} \mathrm{P}\left(\mathrm{RMN}{ }^{31} \mathrm{P}\right)$ em solo sob cobertura de plantas leguminosas. Extratos alcalinos foram obtidos em duas profundidades (0-5 e 5-10 cm) de um Argissolo numa área cultivada com leguminosas herbáceas perenes (Arachis pintoi, Pueraria phaseoloides e Macroptilium atropurpureum). Em áreas adjacentes ao experimento foram coletadas amostras do mesmo solo sob cobertura de floresta tropical secundária (capoeira) e capim-colonião (Panicum maximum). O manejo das leguminosas foi dividido em com e sem a remoção da parte aérea da superfície após o corte das plantas. Os fosfatos em ligações monoésteres foram predominantes em todas as amostras de solo e os fosfatos em ligações diésteres foram acumulados na camada superficial do solo sob floresta secundária. A quantidade de fósforo em ligações diésteres foi maior nas amostras de solo sob cobertura de leguminosas do que sob gramíneas. A permanência da parte aérea na superfície do solo promoveu aumento na razão P diéster/P monoéster. Esses resultados podem ser usados para justificar o aumento da disponibilidade de fósforo para as plantas em solos cultivados com leguminosas.

Termos para indexação: cultivo, desmatamento, culturas de cobertura do solo.

\section{Introduction}

The productivity of most crops is limited by phosphorus (P) availability, especially in strongly weathering soils. In most of the agricultural systems, the maintenance of $\mathrm{P}$ availability to plants growing in these soils is one of the major challenges to be faced because a large portion of the soil P stock is fixed in forms largely unavailable for short term uptake (Velloso et al., 1982) resulting in low plant-available P concentrations (Tiessen \& Moir, 1993). Available P comprises free phosphate ions desorbed and/or dissolved from the soil solid phase or 
released from decomposing organic matter (Fardeu, 1996). An important part of $P$ in soil is organically bound and plays a key role in the P cycle (Dalal, 1977). Stabilization of organic phosphorus (OP) in soil is frequently explained by the incorporation of microbial, vegetation and animal phosphate units into the humified soil organic matter (Stevenson, 1994). Beck \& Sanchez (1994) found that the $\mathrm{NaOH}$-extractable Po fraction is an important source of plant available $\mathrm{P}$ in a non-fertilized Ultisol. Guerra et al. (1996) showed that, despite the lower amounts, OP was intimately related to available $\mathrm{P}$, indicating the potential contribution of this fraction to the availability of P in strongly weathering soils. Neufeldt et al. (2000) confirmed this observation showing that, in an Oxisol, more than $60 \%$ of labile P is organic. However, the analysis of $\mathrm{P}$ fractionation allows only indirect structural characterization of OP compounds. ${ }^{31} \mathrm{P}$ NMR allows a more detailed determination of structural features of organic $\mathrm{P}$ in soils.

Newman \& Tate (1980) quantified the relative amounts of $\mathrm{P}$ in different compounds such as orthophosphates, mono and diester phosphates, phosphonates, and polyphosphates. A series of works has been reported following this approach mainly with temperate soils. Results dealing with tropical soils are more scarce. Forster \& Zech (1993) found that, in tropical rain forest soils, persistent orthophosphate $\mathrm{P}$ monoester makes up an even greater percentage of soil phosphorus. Similar results were observed for Brazilian savannah soils, cultivated or not, and could be explained by the stabilization on $\mathrm{Al}$ and $\mathrm{Fe}$ hydroxides and other clays (Chapuis-Lardy et al., 2001). In a primary tropical forest, Möller et al. (2000) verified that soil organic phosphorus (SOP) is constituted mainly of orthophosphate diesters on the organic layer, whereas on the mineral horizons orthophosphate monoesters dominated the chemical composition of extractable SOP Through ${ }^{31}$ P NMR spectroscopy, Solomons et al. (2002) observed that in tropical sub-humid soils the proportion of the more stable organic orthophosphate monoesters increased following changes in land use compared to that of natural forests.

Characterization of the SOP pool is essential for understanding the $\mathrm{P}$ cycle in tropical agroecosystems where Po contributes significantly to the nutrition of crops.

The objective of this study was to evaluate the influence of soil covering with different leguminous plant on soil organic $\mathrm{P}$ by ${ }^{31} \mathrm{P}$ NMR spectroscopy.

\section{Material and Methods}

The trial was carried out at an Ultisol located at Embrapa Agrobiologia experimental field, in Seropédica, Rio de Janeiro State, Brazil (43 41' W, 22 45' S; 33 m above sea level). Soil chemical properties of the $20 \mathrm{~cm}$ surface were analysed, showing $\mathrm{pH}\left(\mathrm{H}_{2} \mathrm{O}\right), 5.6 ; \mathrm{Al}$, $0.0 \mathrm{mmol}_{\mathrm{c}} \mathrm{dm}^{-3}$ (titration against $\mathrm{NaOH}$ ); $\mathrm{Ca}, 30.0 \mathrm{mmol}_{\mathrm{c}} \mathrm{dm}^{-3}$ and $\mathrm{Mg}, 14.0 \mathrm{mmol}_{\mathrm{c}} \mathrm{dm}^{-3}$ (titration against EDTA); $\mathrm{P}$, $2.0 \mathrm{mg} \mathrm{dm}^{-3}$ (Mehlich 1 extraction and colorimetric determination); K, $72.0 \mathrm{mg} \mathrm{dm}^{-3}$ (Mehlich 1). The mean annual temperature and rainfall are, respectively $24.1^{\circ} \mathrm{C}$ and $1,620 \mathrm{~mm}$. The dry season occurs from April to August.

A completely randomized block design, in a factorial scheme $3 \times 4$ with three replications, was used. Three legumes were evaluated: groundnut (Arachis pintoi Krap. \& Greg.), tropical kudzu (Pueraria phaseoloides (Roxb) Benth.), and siratro (Macroptilium atropurpureum (OC.) Urb). After the first cut, each plot was divided into two subplots: plants were either cut and left on the soil surface or they were cut and removed. Plot size was 3.0x7.0 m and subplot size was $3.0 \times 3.5 \mathrm{~m}$. After 30 months of trial installation soil samples were collected at the depths of $0-5$ and $5-10 \mathrm{~cm}$ with or without plant residues on the soil surface. Soil samples were also collected at the same depths in a closed area covered with secondary vegetation, i.e., mainly formed by $\mathrm{C}_{3}$ plants or by Panicum maximum cv. KK-16.

One hundred grams of air-dried soil were mixed with $1 \mathrm{~L}$ of $0.5 \mathrm{~mol} \mathrm{~L}^{-1} \mathrm{NaOH}$ with $\mathrm{pH}$ adjusted to 7.0 and this was left standing overnight under $\mathrm{N}_{2}$ atmosphere at room temperature. Then all samples were filtered through Whatman 41 filter paper. Subsamples of each filtered extract were digested in $\mathrm{H}_{2} \mathrm{SO}_{4} / \mathrm{HClO}_{4}$ mixture and the total $\mathrm{P}$ analysed (Olsen \& Sommers, 1982). The remainder of each filtrate had the volume reduced under vacuum and at low temperature $\left(40^{\circ} \mathrm{C}\right)$, the ions removed by cation resin column (Amberlit IR-120 $\mathrm{H}^{+}$) and finally freeze-dried. All field samples were collected in triplicate and $\mathrm{P}$ analysis carried out in duplicate.

To prepare the samples for NMR analysis, approximately $1 \mathrm{~g}$ of the freeze-dried extracts was weighed into a $50 \mathrm{~mL}$ plastic centrifuge tube with $2.5 \mathrm{~mL}$ of $\mathrm{D}_{2} \mathrm{O}$. Samples were vortexed for two min. ${ }^{31} \mathrm{P}$ NMR spectra were obtained at $101.27 \mathrm{MHz}$ on a Bruker WM 250 high resolution using a $45^{\circ}$ pulse with a $1.5-\mathrm{s}$ delay and acquisition time of $0.508 \mathrm{~s}$, using phosphoric 
acid as an external reference. The ${ }^{31} \mathrm{P}$ spectra were proton decoupled using an inverse-gated pulse sequence to eliminate the nuclear Overhauser enhancement in order to achieve quantitative results. The assignment of peaks was based on Newman \& Tate (1980), Adams \& Byrne (1989) and Cade-Menun \& Preston (1996). Chemical shifts were measured relative to external $85 \%$ $\mathrm{H}_{3} \mathrm{PO}_{4}$. Peak areas were determined by integration.

\section{Results and Discussion}

No significant differences were observed in total $\mathrm{P}$ contents in the studied samples covered with perennial leguminous. From $40 \%$ to $63 \%$ of total soil P were extracted with $0.5 \mathrm{~mol} \mathrm{~L}^{-1} \mathrm{NaOH}$. In the soil extracts obtained from $P$. phaseoloides the $\mathrm{P}$ contents were lower $\left(119.2 \mathrm{mg} \mathrm{kg}^{-1}\right)$ than those obtained from A. pintoi $\left(157 \mathrm{mg} \mathrm{kg}^{-1}\right)$ and $M$. atropurpureum $\left(128.2 \mathrm{mg} \mathrm{kg}^{-1}\right)$. No relevant differences in P contents were observed with litter being present or not on the soil plots. Nevertheless, it was possible to observe major differences in the distribution of various $\mathrm{P}$ forms for the different vegetable soil covering (Table 1 and Figures 1 and 2). In all soil samples, $\mathrm{P}$ monoesters were the predominant $\mathrm{OP}$ form, representing between $66 \%$ to $95 \%$ of $\mathrm{NaOH}$ extractable phosphorus. Alkali-extractable orthophosphate monoester originates mainly from hydrolysed plant derived phospholipids, including glycerophosphate, inositol phosphate, choline phosphate and others, which are associated with cuticle and middle lamella tissue and cellular membranes and have resonance signals at 3.0 to $5.0 \mathrm{ppm}$ (Newman \& Tate, 1980). The high charge density of monoesters allows rapid adsorption to oxihydroxides, which protect them from degradation (Condron et al., 1990). Turrión et al (2001) found a direct relationship between the Pmonoesters and the amount of clay showing a possible path for monoesters stabilization in soils.

Phosphates in diester linkages (1 to $-1 \mathrm{ppm}$ ) comprise $<1 \%$ to $34 \%$ of total spectra area and consist mainly of glycerol and sugar molecules linked by phosphate groups (Condron et al., 1990) and phospholipids (Newman \& Tate, 1980). Nucleic acids and phosphoric acids residues which serve as a link between adjacent pentoses units could be significant stores of $\mathrm{P}$ in microbial cells. They are readily mineralized in soils, unless stabilized by clay minerals or humic acids (Crecchio \& Stotzky, 1998) and are among the most soluble fractions of Po in soils (Adams, 1990). Amelung et al. (1998) reported that the
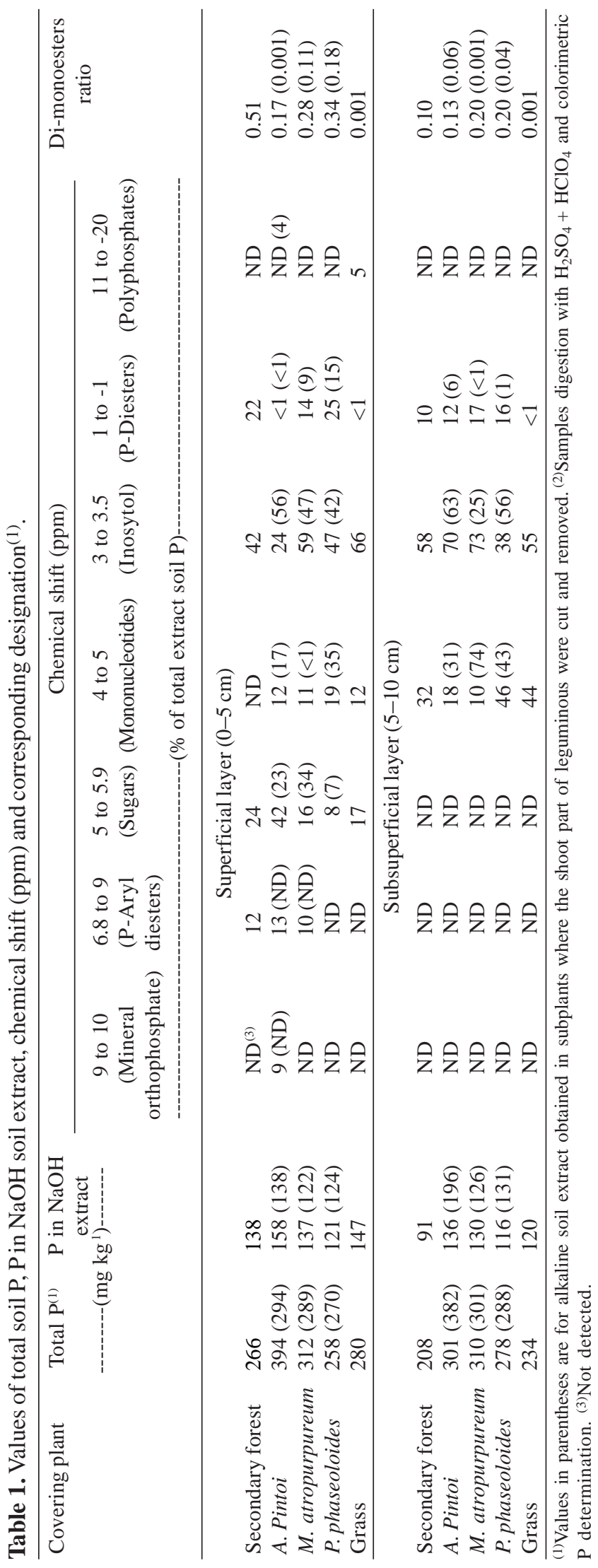

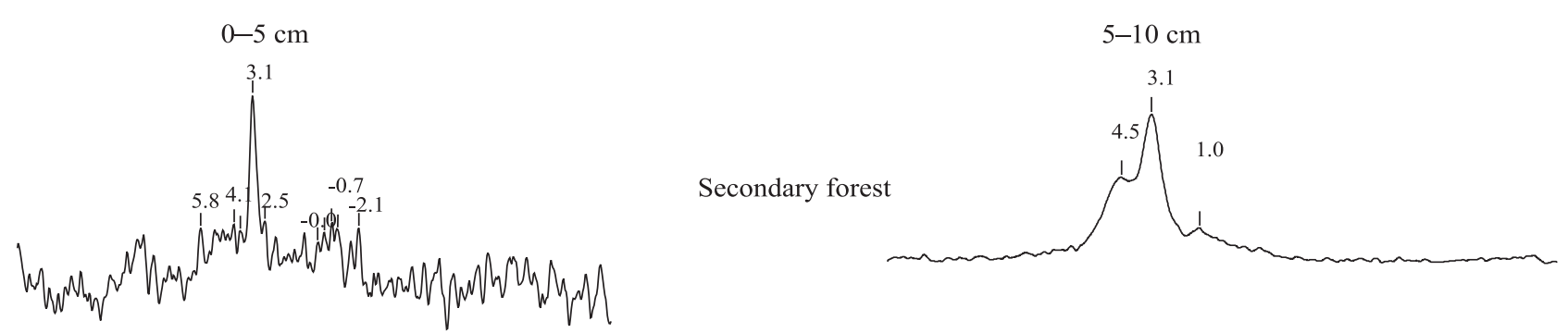

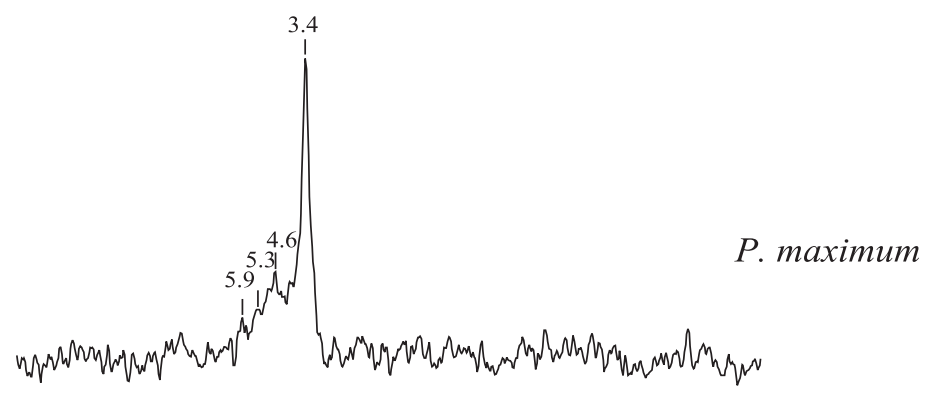
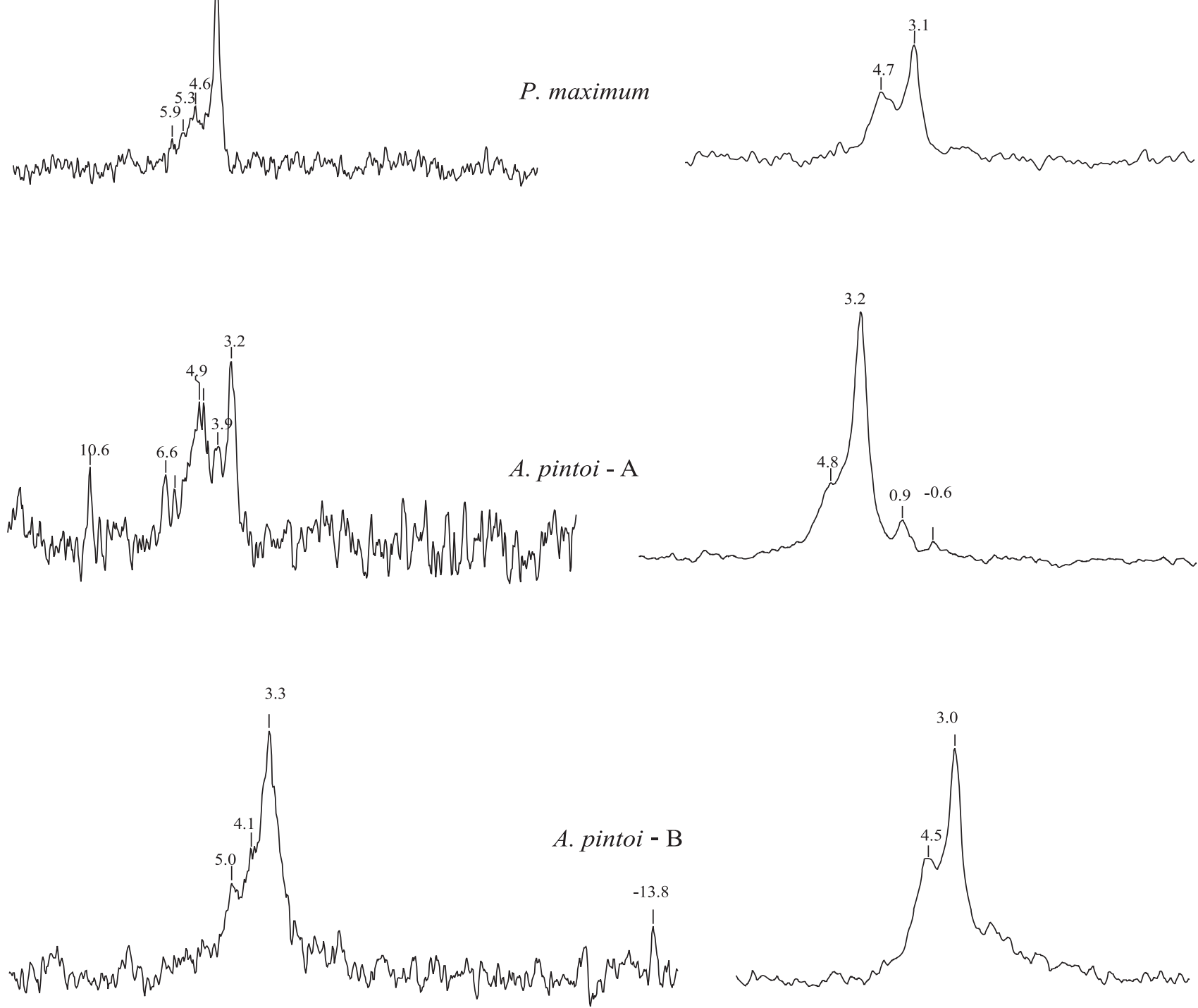

Figure 1. ${ }^{31} \mathrm{P}$ NMR spectra of $0.5 \mathrm{~mol} \mathrm{~L}^{-1} \mathrm{NaOH}$ soil extracts from $0-5$ and 5-10 $\mathrm{cm}$ soil samples under secondary tropical forest, grass (Panicum maximum), and Arachis pintoi. A: without removal of shoot part from leguminous soils plot; B: with removal of shoot part from leguminous soils plot.

Pesq. agropec. bras., Brasília, v.39, n.6, p.589-596, jun. 2004 

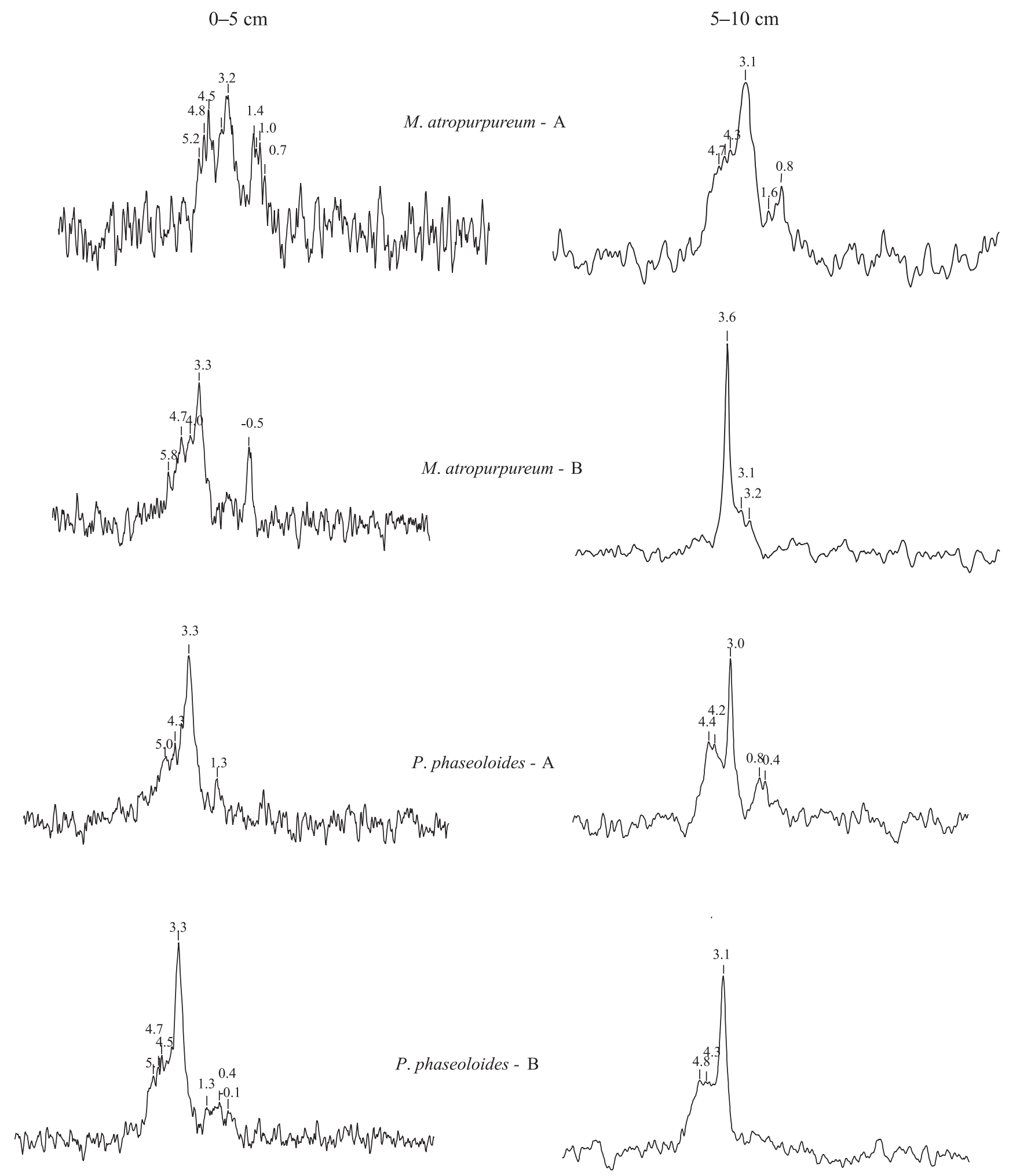

Figure 2. ${ }^{31} \mathrm{P} \mathrm{NMR}$ spectra of $0.5 \mathrm{~mol} \mathrm{~L}^{-1} \mathrm{NaOH}$ soil extracts from 0-5 and 5-10 $\mathrm{cm}$ soil samples under Macroptilium atropurpureum and Pueraria phaseoloides. A: without removal of shoot part from leguminous soils plot; B: with removal of shoot part from leguminous soils plot. 
small amount of orthophosphate diesters produced by plants is very labile, whereas the diester $\mathrm{P}$ produced by microbes is more likely to be stabilized on mineral surfaces, possibly due to the closer proximity of microbes to those surfaces. The percentage of diester $\mathrm{P}$ is normally $<10 \%$ in well-drained soils (Condron et al., 1985). Accumulation of diester $\mathrm{P}$ has been shown only to occur in soils where microbial activity is restrained due to acidity, waterlogging or low temperature (Makarov et al., 1995).

In secondary tropical forest soils, diester P fraction comprise around $34 \%$ of total phosphorus. The apparent vitality and absence of $\mathrm{P}$ deficiency symptoms of forest trees suggest the existence of an efficient, however delicate, natural $\mathrm{P}$ cycle. In soil extracts obtained from leguminous plants covering, the enhancement of microbia activity due to organic residues with low lignin/ $\mathrm{N}$ ratio can promote an enhancement in diester $\mathrm{P}$ amount, which could be stabilized on oxihydroxide fractions, thus being protected from mineralization or accumulated during the dry season. The $\mathrm{P}$ distribution in the areas with $P$. phaseoloides showed the presence of additional signals between 1.0 and $1.4 \mathrm{ppm}$ and at $1.86 \mathrm{ppm}$ due to $\mathrm{P}$ diesters. In addition, with $M$. atropurpureum, an increase in the integration of signals of diesters at 0.57 , 2.57 and $1.46 \mathrm{ppm}$ has been found. This result suggests that the quality of the organic residues has an influence on OP distribution. Regarding soil samples cultivated with A. pintoi at $0-5 \mathrm{~cm}$ of depth, the signals due to $\mathrm{P}$ diesters comprise $12 \%$ but have been attributed solely to aryl phosphate diesters with a resonance at $6.8 \mathrm{ppm}$ according to Bedrock et al. (1994) and Amelung et al. (2001). Furthermore, an increase in monoesters at $3.4 \mathrm{ppm}$ has been observed for A. pintoi covering at $5-10 \mathrm{~cm}$ of depth. An increase has also been observed in $\mathrm{P}$ diesters represented by a signal at 1 to $-1 \mathrm{ppm}$ together with the absence of signals due to aryl phosphate diesters. The low content of lignin and higher $\mathrm{N}$ content compared with other leguminous plants could explain, at least partially, the increase in soil biomass activity with stabilization of aryl phosphate diesters on the superficial layer and the increase of $\mathrm{P}$ monoesters in the subsuperficial layer. Signals for diester P are only at trace levels for the grass alkaline soil extract.

Main differences between ${ }^{31} \mathrm{P}$ spectra due to vegetable cover can be easily observed through analysis of the diester $\mathrm{P} /$ monoester $\mathrm{P}$ ratio. This value for secondary forest samples is 0.51 indicating the presence of orthophosphate diesters at high concentration. Similar results were obtained by Solomons et al. (2002). As for the grass soils, this ratio is much lower than the values reported by Hawkes et al. (1984) and Sumann et al. (1998) for temperate grass soil. The use of $M$. atropurpureum and $P$. phaseoloides as covering crops enhances the diester $\mathrm{P} /$ monoester $\mathrm{P}$ ratio to 0.11 and 0.34 , respectively, and the ratio is more closely related to that observed for secondary tropical forest than to the grass soil extract.

Further relevant signals were observed at 9 to $10 \mathrm{ppm}$ which can be assigned to mineral orthophosphates, suggesting that some orthophosphate $\left(\mathrm{PO}_{4}{ }^{3-}\right)$ ions are associated with inorganic colloids through $\mathrm{Fe}$ and $\mathrm{Al}$ bridges. The presence of inorganic phosphates species in soluble humic substances can be attributed to a slow hydrolysis of organic P or, more probably, by the release of orthophosphate associated with humic substances (Makarov et al., 1997). Other signals present in ${ }^{31} \mathrm{P}$ spectra were assigned to polyphosphates (-20.0 to $-18.0 \mathrm{ppm}$ ) derived from ATP in A. pintoi and grass soil extracts and unknown SOP structures resonating at -2.1 to $-0.8 \mathrm{ppm}$ (Solomons et al., 2002) only in grass soil extracts.

The main effects of crop residues management on SOP distribution in $0.5 \mathrm{~mol} \mathrm{~L}^{-1} \mathrm{NaOH}$ extracts is the increase in the diester $\mathrm{P} /$ monoester $\mathrm{P}$ ratio with the permanence of plant residues on the soil surface. With A. Pintoi, this ratio was increased from 0.11 to 0.17 and from 0.18 to 0.34 for $P$. phaseoloides and M. atropurpureum soil, respectively. Solomons et al. (2002) observed that with better crop residue management the surface litter accumulation reflected a more conservative cycling of organic $\mathrm{P}$ in ecosystems and lead to the increase of orthophosphate diesters compounds, teichoic acids and phosphonates which may apparently represent more labile organic $\mathrm{P}$ species. Guggenberger et al. (1996) also observed an increase of about $10 \%$ in P diesters for the A horizon $(0-10 \mathrm{~cm})$ following a change from continuous growth of grass (Brachiaria decumbens) to a grass/legume (B. decumbens $+P$. phaseoloides) pasture. In agreement with previous reports (Alvey et al., 2001; Daroub et al., 2001; Phiri et al., 2001) P availability increases under soil rotation with leguminous plants.

The results obtained emphasize the importance of leguminous plants with respect to labile organic $P$ species in tropical soils and data from ${ }^{31} \mathrm{P}$ NMR identified the 
main changes in molecular composition in this fraction. Since $\mathrm{P}$ is a non-renewable resource, there is a need to develop agricultural systems based on maximum efficiency of $\mathrm{P}$ use with minimal adverse environmental impacts.

\section{Conclusion}

Herbaceous perennial leguminous plants can help restore soils to their native $\mathrm{P}$ fertility levels by enhancing the amount of $\mathrm{P}$ diesters, which is a labile organic $\mathrm{P}$ fraction.

\section{References}

ADAMS, M.A. ${ }^{31}$ P NMR identification of phosphorus compound in neutral extracts of mountain ash (Eucalyptus regnans $\mathrm{F}$. Muell.) soils. Soil Biology \& Biochemistry, v.22, p.419-421, 1990.

ADAMS, M.A.; BYRNE, L.T. ${ }^{31} \mathrm{P}-\mathrm{NMR}$ analysis of phosphorus compounds in extracts of surface soils from selected karri (Eucalyp tus diversicolor F. Meull.) forests. Soil Biology \& Biochemistry, v.21, p.523-528, 1989.

ALVEY, S.; BAGAYOKO, M.; NEUMANN, G.; BUERKERT, A Cereal/legume rotations affect chemical properties and biologica activities in two West African soils. Plant and Soil, v.231, p.45-54, 2001.

AMELUNG, W.; RODIONOV, A.; URUSEVSKAJA, I.S. HAUMAIER, L.; ZECH, W. Forms of organic phosphorus in zona steppe soils of Russia assessed by ${ }^{31}$ P NMR. Geoderma, v.103, p.335-350, 2001.

AMELUNG, W.; ZECH, W.; ZHANG, X.; FOLLETT, R.F.; TIESSEN, H.; KNOX, E.; FLACH, K.W. Carbon, nitrogen and sulfur pools in particle-size fractions as influenced by climate. Soi Science Society of America Journal, v.62, p.172-181, 1998

BECK, M A.; SANCHEZ, P.A. Soil-phosphorus fraction dynamics during 18 years of cultivation on a typic Paleudult Soil Science Society of America Journal, v.58, p.1424-1431, 1994.

BEDROCK, C.N.; CHESHIRE, M.V.; CHUDEK, J.A GOODMAN, B.A.; SHAND, C.A. ${ }^{31}$ P-NMR studies of humic aci from a blanket peat. In: SENESI, N.; MIANO, T.M. (Ed.). Humic substances in the global environment and implications on human health. Amsterdam: Elsevier, 1994. p.227-234.

CADE-MENUN, B.J.; PRESTON, C.M. A comparison of soil extraction procedures for ${ }^{31} \mathrm{P}$ NMR spectroscopy. Soil Science, v.161, p.770-785, 1996

CHAPUIS-LARDY, L.; BROSSARD, M.; HERVÉ, Q. Assessin organic phosphorus status of cerrado Oxisols (Brazil) using ${ }^{31} \mathrm{P}-$ NMR spectroscopy and phosphomonoesterase activity measurement. Canadian Journal of Soil Science, v.81, p.591-601, 2001 CONDRON, L.M.; FROSSARD, E.; TIESSEN, H.; NEWMAN, R.H.; STEWART, J.W.B. Chemical nature of organic phosphorus in cultivated and uncultivated soils under different environmental conditions. Journal of Soil Science, v.41, p.41-50, 1990.
CONDRON, L.M.; GOH, K.M.; NEWMAN, R.H. Nature and distribution of soil phosphorus as revealed by a sequential extraction method followed by ${ }^{31} \mathrm{P}-\mathrm{NMR}$ analysis. Journal of Soil Science, v.36, p.199-207, 1985

CRECCHIO, C.; STOTZKY, G. Binding of DNA on humic acids: effect on transformation of Bacillus subtilis and resistance to Dnase. Soil Biology \& Biochemistry, v.30, p.1061-1067, 1998.

DALAL, R.C. Soil organic phosphorus. Advances in Agronomy, v.29, p.83-117, 1977.

DAROUB, S.H.; ELLIS, B.G.; ROBERTSON, G.P. Effect of cropping and low-chemical input systems on soil phosphorus fractions. Soil Science, v.166, p.281-291, 2001.

FARDEU, J.C. Dynamics of phosphates in soils: an isotopic outlook. Fertility Research, v.45, p.91-100, 1996.

FORSTER, J.C.: ZECH, W. Phosphorus status of a soil catena under liberian evergreen rain-forest - results of P-31 NMR-spectroscopy and phosphorus adsorption experiments. Zeitschrift fur Pflanzenernahrung und Bodenkunde, v.156, p.61-66, 1993

GUERRA J.G.M.; ALMEIDA, D.L. de; SANTOS, G. de A.; FERNANDES, M.S. Organic phosphorus content in soil samples. Pesquisa Agropecuária Brasileira, v.31, 291-299, 1996.

GUGGENBERGER, G.; HAUMAIER, L.; THOMAS, R.J.; ZECH, W. Assessing the organic phosphorus status of an Oxisol under tropical pastures following native savannah using ${ }^{31} \mathrm{P}$ NMR spectroscopy. Biology and Fertility of Soils, v.23, p.332-339, 1996. HAWKES, G.E.; POWLSON, D.S.; RANDALL, E.W.; TATE, K.R. $\mathrm{A}^{31} \mathrm{P}$ nuclear magnetic resonance study of the phosphorus species in alkali extracts of soils from long-term field experiments. Journal of Soil Science, v.35, p.35-45, 1984.

MAKAROV, M.I.; GUGGENBERGER, G.; ALT, H.G.; ZECH, W. Phosphorus status of Eutric Cambisols polluted by P-containing emissions: results of ${ }^{31} \mathrm{P}-\mathrm{NMR}$ spectroscopy and chemical analysis results of P-31 NMR-spectroscopy and phosphorus adsorption experiments. Zeitschrift fur Pflanzenernahrung und Bodenkunde, v.158, p.293-298, 1995.

MAKAROV, M.I.; MALYSHEVA, T.I.; HAUMAIER, L.; ALT, H.G.; ZECH, W. The forms of phosphorus in humic and fulvic acids of a toposequence of alpine soils in the northen Caucasus. Geoderma, v.80, p.61-73, 1997

MÖLLER, A.; KAISER, K.; AMELUNG, W.; NIAMSKUL, C.; UDOMSRI, S - PUTHAWONG, M : HAUMAIER, L.; ZECH, W. Relationships between $\mathrm{C}$ and $\mathrm{P}$ forms in tropical soils Thailand as assessed by liquid-state ${ }^{13} \mathrm{C}$ - and ${ }^{31} \mathrm{P}$-NMR spectroscopy. Australian Journal of Soil Research, v.38, p.1017-1035, 2000.

NEUFELDT, H.; SILVA, J.E. da; AYARZA, M.A.; ZECH, W. Landuse effects on phosphorus fractions in Cerrado Oxisols. Biology and Fertility of Soils, v.31, p.30-37, 2000.

NEWMAN, R.H.; TATE, K.R. Soil phosphorous characterization by ${ }^{31} \mathrm{P}$ nuclear magnetic resonance. Communications in Soil Science and Plant Analysis, v.11, p.835-842, 1980.

OLSEN, S.R.; SOMMERS, L.E Phosphorus. In: PAGE, A.L. (Ed.). Methods of soil analysis: chemical and microbiological properties. Madison: American Society of Agronomy, 1982. pt.2, p.403-430. 
PHIRI, S ; BARRIOS, E.; RAO, I.M.; SINGH, B.R. Changes in soil organic matter and phosphorus fractions under planted fallows and a crop rotation system on a Colombian volcanic-ash soil. Plant and Soil, v.23, p.211-223, 2001.

SOLOMONS, D.; LEHMAMN, J.; MAMO, T.; FRITZSCHE, F; $\mathrm{ZECH}, \mathrm{W}$. Phosphorus compounds and dynamics as influenced by land use changes in the sub-humid Ethiopian highlands. Geoderma v.105, p.21-48, 2002

STEVENSON, F.J. Humus chemistry: genesis, composition, reactions. New York: J. Wiley, 1994. 496p.

SUMANN, M.; AMELUNG, W.; HAUMAIER, L.; ZECH, W. Climatic effects on soil organic phosphorus in the North American Great Plains identified by phosphorus-31 nuclear magnetic reso- nance. Soil Science Society of America Journal, v.62, p.15801586, 1998.

TIESSEN, H.; MOIR, J.O Characterization of available P by sequential extraction. In: CARTER, M.R. (Ed.). Soil sampling and methods of analysis. Boca Raton: Lewis, 1993. p.75-86.

TURRIÓN, M.B.; GALLARDO, J.F.; HAUMAIER, L.; GONZÁLEZ, M.I. ZECH, W, ${ }^{31}$ P-NMR characterization of phosphorus fractions in natural and fertilized forest soils. Annals of Forest Science, v.58, p.89-98, 2001.

VELLOSO, A.C.X.; SANTOS, G. de A.; RAMOS, D.P. Capacidade de troca de cátions e adsorção de fosfato de solos sob vegetação do Cerrado do Amapá. Pesquisa Agropecuária Brasileira, v. 17, p.2732, 1982.

$\overline{\text { Received on November 11, } 2003 \text { and accepted on March 12, } 2004}$ 